\title{
PERAN MEDIA SOSIAL DALAM PENINGKATAN PARTISIPASI PEMILIH PEMULA DIKALANGAN PELAJAR DI KABUPATEN BOGOR
}

\author{
Ike Atikah Ratnamulyani ${ }^{1}$ dan Beddy Iriawan Maksudi $^{2}$
}

${ }^{1}$ Program Studi Ilmu Komunikasi, Fakultas Ilmu Sosial dan Ilmu Politik, Universitas Djuanda Bogor ${ }^{2}$ Program Ilmu Administrasi Negara, Fakultas Ilmu Sosial dan Ilmu Politik, Universitas Djuanda Bogor E-mail: ikea.ratnamulyani@gmail.com

\begin{abstract}
ABSTRAK. Seiring dengan perkembangan teknologi informasi berbasis internet, maka semakin penting peran media sosial online sebagai salah satu faktor yang dapat memberikan efek positif dalam peningkatan partisipasi politik dikalangan pelajar sebagai pemilih pemula di dalam pemilihan umum. Namun, realitasnya para politisi atau partai politik yang berkompetisi di pemilihan anggota legislatif di Kabupaten Bogor pada tahun 2014 belum optimal dalam memanfaatkan media sosial berbasis internet tersebut. Dampaknya tingkat partisipasi politik pemilih pemula dikalangan pelajar rendah. Oleh karena itu, penelitian ini memiliki tujuan (1) untuk mendeskripsikan pengguna media sosial dikalangan pelajar sebagai pemilih pemula; (2) untuk mendeskripsikan pengguna media sosial berbasis internet dikalangan politisi/partai politik (3) untuk mengetahui konten pesan kampanye politik para politisi di media sosial. Metode penelitian ini bersifat deskriptif analisis, ialah untuk menggambarkan, menganalisis dan menginterpretasikan data. Tehnik pengambilan data dengan cara: observasi, wawancara, kuesioner dan FGD (Focus Group Discations). Hasil penelitian menunjukan bahwa pengguna media sosial semakin masif di kalangan pelajar sebagai pemilih pemula di kabupaten Bogor untuk mengakses informasi tentang pemilu, yaitu sebagai pengguna Twiteer 35\%, Facebook 28\%, dan Instagram 28\%. Sedangkan dikalangan para politisi/partai politik dalam kampanye politik masih rendah dalam penggunaan akun media sosial (82,7\%). Kemudian konten kampanye politik para politisi dalam media sosial kurang menarik (94,2\%). Adapun saran untuk para politisi antara lain: (1) Pemanfaatkan media sosial dalam kampanye pemilu secara optimal (2). Konten pesan politik sebaiknya disesuaikan dengan ciri khas pemilih pemula, seperti: sederhana, praktis, menarik dan mudah dipahami oleh mereka.
\end{abstract}

Kata kunci: Media sosial, partisipasi politik, pemilu legislatif, pemilih pemula, kalangan pelajar

\section{THE ROLE OF SOCIAL MEDIA IN THE IMPROVEMENT OF SELECTED PARTICIPATION OF STUDENTS BASED ON STUDENTS IN BOGOR REGENCY}

\begin{abstract}
With the development of Internet-based information technology, the more important the role Along of online social media as one of the factors that can provide a positive effect in increasing political participation among students as novice voters in the general election. However, the reality of politicians or political parties that compete in the election of legislative members in Bogor Regency in 2014 has not been optimal in utilizing the internet-based social media. The impact of voter participation rate of beginner among student is low. Therefore, this study has a purpose (1) to describe social media users among learners as novice voters; (2) to describe users of internet-based social media among politicians (3) to find out the political campaign messages of politicians in social media.This research method is descriptive analysis, is to describe, and interpret data. Techniques of data collection by: interview, questionnaire and FGD. The results showed that social media users are increasingly massive among students as novice voters to access information about the election, ie Twiteer 35\% users, 28\% Facebook, and 28\% Instagram. While the politicians in political campaigns are still low in the use of social media accounts (82.7\%). Then the political campaign content of politicians in social media is less interesting (94.2\%). (1) Utilizing social media in election campaigns optimally (2). The content of political messages should be tailored to the characteristics of beginner voters, such as: simple, practical, interesting and easily understood by them.
\end{abstract}

Key words: Social media, political participation, legislative elections, novice voters, students

\section{PENDAHULUAN}

Ketika perkembangan teknologi semakin pesat, terutama di bidang teknologi informasi berbasis internet maka peran media komununikasi semakin penting. Oleh karena itu, sekarang media telah menjadi salah satu kebutuhan utama bagi setiap orang. Hal ini seiring dengan ditemukannya perangkat-perangkat media yang berbasis internet, sehingga informasi menjadi sesuatu yang mudah ditemukan dibelahan dunia ini, dengan mengakses melalui internet mengenai informasi, hiburan, pendidikan, politik, ekonomi dan lain-lain.

Berdasarkan fenomena tersebut, komunikasi yang pada awalnya hanya sebatas proses interaksi personal secara face to face, kini berkembang secara online berbasis iternet. Dalam hal ini, salah satu komunikasi berbasis internet yang banyak digunakan adalah media sosial. Media sosial adalah sebuah media online. Dengan hadirnya media berbasis internet (media online) tersebut menunjukkan telah terjadi pergeseran arah penggunaan media komunikasi, yang semula bersifat klasik (media elektronik dan cetak) dan kini mengalami perubahan kepada media baru (new media) berbasis internet yang menjadi saluran akses media sosial dalam berbagai bidang, yaitu pendidikan, budaya, sosial, ekonomi, hukum, juga politik, misalnya digunakan di dalam kampanye pemilu untuk mensosialisaikan visi, misi, dan program kerja seorang kandidat kepala daerah misalnya. 
Media sosial dijadikan sebagai strategi komunikasi politik adalah merupakan relatif baru dan menjadi fenomena hangat hingga kini. Misalnya, yang paling mendapat sorotan, yaitu ketika kampanye politik kandidat presiden Amerika Serikat, Barac Obama dan tim suksesnya pada 2008 menggunakan media baru untuk menyebarkan informasi seputar program dan kegiatan kampanye dalam rangka menggalang simpati dan dukungan masyarakat Amerika pada saat itu. Di Indonesia, penggunaan media sosial sebagai alat komunikasi politik yang paling marak ketika pemilihan presiden Republik Indonesia pada 2014. Maraknya media sosial di dunia maya dalam kampanye Pilpres 2014 berkaitan dengan makin banyaknya pengguna internet di negeri ini. Studi Asosiasi Penyelenggara Jasa Internet Indonesia (APJII) menemukan "pengguna internet di Indonesia meningkat sekitar 20-30 persen, yaitu menjadi 80 juta orang pada akhir 2013. Hal ini berarti pertumbuhannya mencapai 33,3\%" (http://nasional. kompas.com/read/2014/06/24/0245002/).

Varian media sosial yang tengah berkembang dan banyak diminati orang adalah Facebook, Twitter, WhatsApp, Youtube, dansebagainya. Jikamediatradisional menggunakan media cetak dan media broadcast, maka media sosial menggunakan internet. Dengan demikian, media sosial sebagai sarana komunikasi memiliki peran membawa orang (penggunanya) untuk berpartisipasi secara aktif dengan memberi kontribusi dan feedback secara terbuka, baik untuk membagi informasi maupun memberi respon secara online dalam waktu yang cepat.

Dalam konteks ini, dilihat dari kasus pemilihan anggota legislatif pada 2014 di Kabupaten Bogor di temukan bahwa pada umumnya para politisi yang ikut berkompetisi dalam pemilihan anggota legislatif kurang memanfaatkan media sosial secara optimal. Dengan kata lain, cendrung masih menggunakan gaya kampannye dalam komunikasi politik bersifat konvensional, dari pada menggunakan jejaring internet, seperti web site, blog, facebook, twitter, whatsApp dan sebagainya. Padahal, lingkungan telah berubah, yaitu datangnya era baru yang disebut dengan era teknologi digital, atau disebut pula dengan istilah "new media" yang bersifat kontemporer. Perangkat teknologi yang bersifat multimedia mulai digunakan sebagai sarana sosialisasi dan kampanye para calon kadidat anggota legislatif. Hal inilah yang menyebabkan tingkat partisipasi politik pemilih, khususnya pemilih pemula dikalangan pelajar di Kabupaten Bogor masih rendah pada pemilu legislatif 2014. (http://www.pemilu.go.id).

Berdasarkan paparan tersebut, maka masalah penelitian ini dapat dirumuskan sebagai berikut; (a) Bagaimana tingkat pemilih pemula melalui jaringan internet di Kabupaten Bogor (b) Bagaimana tingkat pengetahuan tentang pemilu dikalangan pelajar dan mahasiswa di Kabupaten Bogor. (c) Bagaimana merancang pengguna media sosial dikalangan pelajar sebagai pemilih rancang model komunikasi politik berbasis multi-media sosial untuk meningkatkan partisipasi politik pemilih pemula melalui multi-media sosial.

Istilah peran dalam Kamus Besar Bahasa Indonesia "mempunyai arti pemain sandiwara (film), tukang lawak pada permainan makyong, perangkat tingkah yang diharapkan dimiliki oleh orang yang berkedudukan di masyarakat" (Departemen Pendidikan Nasional, 2005: 751). Bauer berpendapat bahwa peran (seperti dikutip Haris, 2012: 204) “sebagai presepsi mengenai cara orang itu diharapkan berperilaku atau kesadaran mengenai pola perilaku atau fungsi yang diharapkan dari orang tersebut". Dari pengertian peran tersebut, dapat disimpulkan bahwa peran merupakan karakter yang dibawakan oleh seseorang dalam sebuah panggung permainan. Adapun dalam pengertian lain bahwa peran adalah suatu fungsi yang diharapkan dari seseorang yang sedang memegang jabatan. Jadi, suatu peran yang menyebabkan perilaku seseorang memiliki pengaruh dalam menjalankan fungsinya.

Istilah media berasal dari bahasa Latin dan merupakan bentuk jamak dari kata "Medium” yang secara harfiah berarti "perantara" yaitu perantara sumber pesan (a source) dengan penerima pesan (a receiver). (http:// digilib.unila.ac.id/12294/3/BAB\%20II.pdf, diakses 16 Feb 2017).

Sementara itu, pengertian media dalam Kamus Besar Bahasa Indonesia "mempunyai arti alat (sarana) komunikasi seperti koran, radio, televise, film, poster, dan spanduk” (Departemen Pendidikan Nasional, 2005: 461). Menurut Cangara berpendapat bahwa "media adalah alat atau sarana yang digunakan untuk menyampaikan pesan dari komunikator kepada khalayak." (Cangara,2006: 119). Dari pengertian media di atas, dapat disimpulkan bahwa media adalah suatu sarana atau perantara yang dapat digunakan oleh seseorang atau disebut komunikator untuk menyampaikan pesan atau informasi kepada khalayak, baik secara langsung dengan tatap muka maupun tidak lansung melalui koran, radio, televisi, film, foster dan spanduk.

\section{Pengertian Komunikasi}

Menurut Mingkid berpendapat metode komunikasi merupakan cara yang dipergunakan dalammengadakan hubungan dengan orang lain baik di dalam maupun di luar organisasi yang dalam kategori komunikasi metode lisan dan tulisan. Secara konseptual, pemahaman akan media komunikasi dapat terlihat dari pemikiran Harold Laswell dalam In which channel yaitu saluran atau media yang digunakan dalam proses komunikasi apakah langsung atau tatap muka dan sebagainya. Dalam tulisan lainnya, Mangkid mengutip pendapat Siagian Pada bagian lainnya juga mengutip pendapat Onong bahwa poses komunikasi setidaknya melibatkan: Saluran, ialah alat yang digunakan oleh komunikator untuk menyampaikan pesan unsurunsur komunikasi antara lain adalah media yaitu sarana 
atau saluran yang mendukung pesan bila komunikan jauh tempatnya atau banyak jumlahnya. (Mingkid, 2012: 190)

\section{Pengertian Sosial}

Ada beberapa pengertian sosial yang dikemukakan para ahli ilmu sosial, seperti yang dikutif Nasrullah sebagai berikut.

Durkheim berpendapat bahwa sosial "merujuk pada kenyataan sosial (the social as social facts) bahwa setiap individu melakukan aksi yang memberikan kontribusi kepada masyarakat. Pernyataaan ini menegaskan bahwa pada kenyataannya media dan semua perangkat lunak (softwere) merupakan sosial dalam makna keduanya merupakan produk dari proses sosial." (Nasrullah, 2017: 7).

Sementara itu, Marx mengungkapkan bahwa:

Memaknai sosial itu merujuk pada saling bekerjasama (co-operative work). Dengan melihat fakta bahwa kata sosial bisa dipahami dari bagaimanna setiap individu saling bekerjasama, apapun kondisinya, sebagaimana yang terjadi dalam proses produksi di mana setiap mesin saling bekerja dan memberikan kontribusi terhadap produk. Dalam kajian Marx ini, ada penekanan bahwa sosial berarti terdapatnya karakter kerjasaama atau saling mengisi di antara individu dalam rangka membentuk kualitas baru dari masyarakat. (Nasrullah,2017: 7)

Dari pengertian sosial tersebut, dapat disimpulkan bahwa kata sosial adalah merupakan tindakan atau aksi dan interaksi seseorang dengan orang lainnya serta melakukan kerjasama untuk mencapai tujuan, yaitu memberikan kontribusi kepada masyarakat.

\section{Pengertian Media Sosial}

Dari dua kata media dan sosial yang telah dijelaskan tersebut, kemudian kita gabungkan menjadi kata media sosial. Berikut ini ada beberapa definisi dari media sosial antara lain yang dikemukakan oleh Mandibergh berpendapat bahwa "media sosial adalah media yang mewadahi kerjasama di antara pengguna yang menghasilkan konten (user generated content)". (Nasrullah, 2017: 11).

Sementara itu, Boyd menjelaskan bahwa: Media sosial sebagai kumpulan perangkat lunak yang memungkinkan individu maupun komunitas untuk berkumpul, berbagi, berkomunikasi, dan dalam kasus tertentu saling berkolaborasi atau bermain. Media sosial memiliki kekuatan pada user-generated content (UGC) di mana konten dihasilkan oleh pengguna, bukan oleh editor sebagaimana di institusi media massa. (Nasrullah, 2017: 11)

Dari dua definisi tersebut, dapat disimpulkan bahwa media sosial adalah sarana yang merupakan medium berbasis teknologi internet (media online) yang memungkinkan seseorang dapat berinteraksi sosial, berkomunikasi dan berkerjasama, serta berbagi dengan orang lainnya.
Selain itu, penggunanya dengan mudah berpartisipasi di dalamnya, berbagi dan menciptakan pesan. Dalam hal ini, ada beberapa situs media sosial yang populer sekarang ini antara lain: Blog, Twitter, Facebook WashApps, BMM, Line, Wikipedia dan lain-lain.

\section{Media Massa}

Menurut Prasetya berpendapat Media massa sebagai salah satu bagian yang tidak terpisahkan di masyarakat telah memberikan pengaruh yang begitu signifikan di masyarakat. Berbagai bentuk tayangan di media massa mampu menampilkan realita sosial di masyarakat. Media massa yang telah mengalami perkembangan begitu pesat juga mampu membentuk opini public melalui tayangan yang disajikannya, seperti berita misalnya. Televisi sebagai salah satu media massa yang paling besar memberikan pengaruh merupakan media yang paling banyak dikonsumsi oleh masyarakat. (Prasetya, 2013: 233)

\section{Peran Media Sosial Dalam Politik}

Sebagaimana telah diuraikan bahwa media sosial adalah sebuah media online yang menggunakan teknologi berbasis internet yang mendukung interaksi sosial, sehingga mengubah komunikasi menjadi dialog interaktif yang timbal balik. Dalam perkembangannya, media sosial menjadi penting sebagai sarana yang efektif dalam proses komunikasi politik, khususnya dalam konteks kampanye pemilu yang dapat menjadi perantara para politisi dengan konstituennya,yaitu antara komunikator dan komunikan secara jarak jauh dan bersifat massif. Oleh karena itu, melalui media sosial, komunikator dapat melakukan komunikasi politik dengan para pendukung atau konstiuennya, yaitu untuk membangun atau membentuk opini publik dan sekaligus memobilisasi dukungan politik secara masif. Pemanfaatan media sosial juga telah meningkatkan jaringan komunikasi politik, relasi politik dan partisipasi politik masyarakat dalam pemilu.Hal ini sering kita jumpai dalam masa-masa kampanye politik para kandidat calon Kepala Daerah yang sedang maju dalam kompetisi pemilihan Kepala Daerah (Pilkada), maupun kandidat calon presiden dalam Pilpres, dan dalam pemilihan anggota legislatif(Pileg).

\section{Pengertian Partisipasi Politik}

Secara umum, partisipasi adalah keikutsertaan atau keterlibataan setiap warga masyarakat untuk mempergunakan hak dalam menyampaikan pendapat dalam proses pengambilan keputusan yang menyangkut kepentingan masyarakat, baik secara langsung maupun tidak langsung. Surbakti menjelaskan bahwa "partisipasi politik ialah segala keikutsertaan warga negara biasa dalam menentukan segala keputusan yang menyangkut atau mempengaruhi hidupnya" (Surbakti, 1999: 140). Menurut Budiardjo bahwa partisipasi politik adalah "kegiatan seseorang atau sekelompok orang untuk ikut 
serta secara aktif dalam kehidupan politik, antara lain seperti memilih pimpinan negara dan secara langsung atau tidak langsung, mempengaruhi kebijakan pemerintah" (Budiardjo, 2008 : 367).

Dari pengertian partisipasi politik tersebut, dapat disimpulkan bahwa partisipasi politik adalah keterlibatan individu atau kelompok sebagai warga negara dalam proses politik yang berupa kegiatan yang bertujuan untuk berpartisipasi aktif dalam kehidupan politik dalam rangka mempengaruhi kebijakan pemerintah.

\section{Bentuk-bentuk Partisipasi Politik}

Bentuk partisipasi politik seorang tampak dalam aktivitas-aktivitas politiknya. Bentuk partisipasi politik yang paling umum dikenal adalah pemungutan suara (voting) entah untuk memilih calon wakil rakyat atau untuk memilih Kepala Negara (Maran, 2001: 148).

Menurut Michael Rush dan Philip Althoff (Maran, 2001: 148) mengidentifikasi bentuk-bentuk partisipasi politik yaitu: (a) menduduki jabatan politik atau administrasi; (b) mencari jabatan politik atau administrasi; (c) menjadi anggota aktif dalam suatu organisasi politik; (d) menjadi anggota pasif dalam suatu organisasi politik; (e) menjadi anggota pasif dalam suatu organisasi semi politik; (f) menjadi anggota aktif dalam suatu organisasi semi politik; (g) partisipasi dalam rapat umum, demontrasi, dsb; (h) partisipasi dalam diskusi politik internal; dan (i) partisipasi dalam pemungutan suara.

\section{Pengertian Pemilih Pemula}

Dalam hal ini yang dimaksud dengan pemilih adalah warga Negara Indonesia yang telah genap berumur 17 tahun atau lebih atau sudah/pernah kawin(Pasal 1 ayat (22) UU No 10 tahun 2008 tentang Pemilu). Kemudian pemilih yang mempunyai hak memilih adalah warga Negara Indonesia yang didaftar oleh penyelenggara pemilu dalam daftar pemilih dan pada hari pemungutanm suara telah genap berumur 17 (tujuh belas) tahun atau lebih atau sudah/pernah kawin. (Pasal 19 ayat 1 dan 2 UU No. 10 tahun 2008 tentang Pemilu).

Sementara itu, pemilih pemula adalah terdiri dari masyarakat yang telah memenuhi syarat untuk memilih, yang baru pertama kali melakukan penggunaan hak pilihnya. Mereka biasanya adalah pelajar berusia 1721 tahun, namun ada juga kalangan muda lainnya yang baru pertama kali akan menggunakan hak pilihnya dalam pemilu yakni para mahasiswa semester awal dan kelompok pemuda lainnya yang pada pemilu periode sebelumnya belum genap berusia 17 tahun (Modul 1 KPU, Pemilih Untuk Pemula. 2010: 48)

Adapun syarat-syarat yang harus dimiliki seseorang untuk dapat menjadi pemilih adalah: 1. Warga Negara Indonesia yang berusia 17 tahun atau lebih atau sudah/ pernah kawin. 2. Tidak sedang terganggu jiwa/ingatannya 3. Terdaftar sebagai pemilih 4.Bukan anggota TNI/Polri 5. Tidak sedang dicabut hak pilihnya 6.Terdaftar di Daftar
Pemilih Tetap (DPT) 7.Khusus untuk Pemilukada calon pemilih harus berdomisili sekurang kurangnya 6 (enam) bulan di daerah yang bersangkutan (Sekretariat Jenderal KPU, 2010:1).

\section{Pengertian Pemilihan Umum}

Secara umum, pengertian Pemilihan Umum, yang selanjutya disingkat Pemilu adalah suatu proses politik untuk memilihorang-orang yang akan mendudukijabatanjabatan politik, seperti di lembaga eksekutif maupun legislatif. Pemilu ini diadakan untuk mewujudkan negara yang demokrasi, di mana para pemimpinnya dipilih berdasarkan suara mayoritas terbanyak. Oleh karena itu, pemilu adalah merupakan salah satu cara dalam sistem demokrasi untuk memilih wakil-wakil rakyat yang akan duduk di lembaga perwakilan rakyat, serta juga memilih Presiden dan Wakil presiden. Menurut Ramlan: "Pemilu diartikan sebagai "mekanisme penyeleksian dan pendelegasian atau penyerahan kedaulatan kepada orang atau partai yang dipercayai" (Surbakti,1992: 181).

Pemilu tidak hanya diperuntukan memilih eksekutif (Presiden dan Wakil Presiden), tetapi juga untuk memilih badan legislatif (memilih wakil-wakil yang duduk dalam lembaga perwakilan rakyat) (UU. No. 8 tahun 2012 dan UU. No. 15 tahun 2011), yaitu:

1) anggota DPR,

2) $\mathrm{DPD}$,

3) DPRD Provinsi, dan

4) DPRD Kabupaten /Kota

\section{METODE}

Penelitiaan ini menggunakan metode kualitatifdeskriptif. Metode kualitatif adalah "disebut pula metode penelitian naturalistik karena penelitiannya dilakukan pada kondisi yang alamiah" (Sugiyono, 2014: 13). Pendekatan deskriptif adalah "suatu penelitian yang didasarkan pada data yang ada atau penyelidikan yang bertujuan pada pemecahan masalah (Winarno, 2002: 175). Dengan demikian, pendekatan kualitatif-deskripsi adalah penelitian yang menggambarkan data kualitatif sebagaimana adannya, dan kemudian data tersebut dianalisis makna dibalik fakta yang tampak.

Penelitian ini melibatkan 40 Sekolah Menengah Umum Negeri (SMAN) se Kabupaten Bogor. Populasi sasaran dalam penelitian ini adalah pemilih pemula yang masih berstatus pelajar tingkat SMU dan mahasiswa semester satu yang sudah memenuhi cukup umur 17 tahun. Penarikan sampel berdasarkan teknik purposif (purposive sampling) kepada siswa/siswi kelas III yang sudah memenuhi syarat memilih atau mencoblos pada pemilihan umum. Setiap sekolah (SMAN sampel) akan diwakili oleh lima orang calon pemilih pemula, yang seluruhnya 100 siswa dari 20 sekolah sampel. Sampel lain diambil dari kalangan umum sebesar 50 orang pemilih pemula yang telah memenuhi syarat memilih. Jumlah sampel keseluruhan berjumlah 150 orang. 
Teknik pengumpulan data menggunakan instrumen; (1) observasi, yaitu mengadakan pengamatan secara langsung, (2) kuesioner, bersifat tertutup, dan (3) Focus Group Discussion (FGD) dengan tujuan untuk mendapatkan data dan informasi yang mendalam. Adapun data sekunder diperoleh dari literatur-literatur yang terkait dengan kajian penelitian.

Kemudian sebagai pisau analisis, didukung dengan teori-teori yang berkaitan dengan teori penggunaan media dan teori komunikasi politik, untuk melihat bagaimana kandidat anggota legislatif memanfaatkan media sosial sebagai media komunikasi politik dan masyarakat meresponnya.

\section{HASIL DAN PEMBAHASAN}

Analisis data informan merupakan analisis mengenai data-data pribadi untuk melengkapi data penelitian. Dari 150 informan, bahwa jumlah informan yang berkelamin perempuan menduduki urutan pertama sebesar 58\%, sedangkan urutan kedua diduduki oleh informan laki-laki sebesar 42\%. Sementara itu, dilihat dari usia informan bervariasi, yaitu dimulai usia 21 sekitar 34\%, urutan berikutnya $29 \%$ berusia 16 tahun, $16,9 \%$, berusia 18 tahun $12,8 \%$, dan berusia 20 tahun sekitar $6,7 \%$. Terdapat variasi usia informan tersebut, pertama karena usia dimulainya sekolah berbeda, kedua, dari 150 informan yang dijadikan sampel, selain sejumlah 100 informan dari kalangan siswa SMAN, dan 50 informan adalah mahasiswa.

\section{Analisis Pemanfaatan Media Sosial}

Bagian ini merupakan gambaran pemanfaatan media sosial oleh pemilih pemula dari kalangan pelajar, yang diukur dengan: (1) pemanfaatkan fasilitas internet melalui Handphone, Tablet, dan Laptop dikalangan pelajar sebagai pemilih pemilih pemula, (2) pemanfaatan media sosial dengan berbagai aplikasi didalamnya dikalangan pelajar sebagai pemilih pemula; (3) Frekuensi pemanfaatan media sosial dikalangan pelajar sebagai pemilih pemula; dan (4) Gambaran keinginanan para pelajar sebagai pemilih pemula dalam keterlibatan dalam media sosial, dan (5) Keinginanan Keterlibatan dalam membuat akun Media sosial; (6) dan (7) Urgensi pemanfaatan media sosial dikalangan pelajar.

\section{Pemanfaatkan Fasilitas Internet}

Bagian ini menggambarkan tentang pemanfaatan fasilitas internet melalui handphone, tablet, dan laptop dikalangan pelajar sebagai pemilih pemula. Terlihat bahwa pengguna internet melalui handphone sebesar $96,7 \%$, dan hanya $3 \%$ yang menggunakan tablet, dan laptop. Dari fakta ini, menunjukkan bahwa mayoritas di kalanngan pelajar sebagai pemilih pemula di Kabupaten Bogor sangat aktif mengakses internet melalui handphone.

\section{Pemanfaatan berbagai aplikasi media sosial}

Pemanfaatan berbagai aplikasi media sosial dengan mengakses internet di kalangan pelajar di Kabupaten Bogor menunjukkan bahwa Facebook $(85,3 \%)$, Whats App (72,7\%), Instagram (71,3\%), Path (14,7\%), Line (18,7\%), dan sisanya Youtube, Pinnterest. Ask fm, Telegram, Line, Kakaotalk masing-masing hanya 0,07\%. Hal ini memiliki makna bahwa penggunaan aplikasi media sosial dikalangan pelajar sudah masif, yang ditunjukkan dengan angka $85,3 \%$ yang pemanfaatkan Facebook, diikuti dengan 72,7\% WhatsApp, dan 71,3\% Instagram. (Hasil Penelitian, 2017)

\section{Frekuensi Pemanfaatkan aplikasi media sosial}

Pemanfaatan aplikasi media sosial, yaitu dilihat dari frekuensi mengakses aplikasi media sosial dikalangan pelajar di Kabupetn Bogor yaitu ditunjukkan dengan angka 34,7 \% yang paling sering diakses adalah WhatsApp, 28 \%, dan Faccebook urutan kedua, dan 5\% adalah BBM, Line dan lainnya Hal ini bermakna pada umumnya pemilih pemula dikalangan pelajar sering pemanfaatkan aplikasi di dalam berkomunikasi atau mencari informasi adalah pertama melalui WhatsApp, kedua Instagram dan Facebook, dan ketiga BBM, Line. (Hasil Penelitian, 2017)

\section{Keinginanan keterlibatan di media sosial}

Indikator minat keinginan keterlibatan dalam media sosial dikalangan pelajar sebagai pemilih pemula di Kabupaten Bogor dapat ditunjukkan dengan angka 92,7\% menyatakan memiliki keinginan besar untuk terlibat didalam kegiatan berkomunikasi melalui media sosial, dan 5\% yang menyatakan kurang memiliki minat, dan $0 \%$ menyatakan tidak sama sekali berkeinginan terlibat untuk pemanfaatkan media sosial serta hanya $1 \%$ yang sama sekali tidak memiliki keinginan terlibat di media soaial. Hal ini jelas hampir mayoritas di kalangan pelajar memiliki minat besar untuk memanfaatkan media sosial untuk melakukan komunikasi. (Hasil Penelitian, 2017)

\section{Alasan keterlibatan di akun media sosial}

Untuk mengetahui apa alasan para pelajar sebagai pemilih pemula untuk terlibat di media sosial, maka dapat dilihat dari hasil penelitian yang menujukkan angka $77,3 \%$ beralasan karena kesadaran sendiri, 10,7 $\%$, pengaruh teman sekolah, 5\% dorongan teman dari lingkungan rumah, $4 \%$ dorongan dari orang lain, dan 3\% untuk dianggap modern. Hal ini berarti hampir mayoritas kalangan pelajar di Kabupaten Bogor telah memiliki kesadaran yang tinggi untuk terlibat dengan pemanfaatkan akun media sosial untuk berkomunikasi dan mengakses informasi. (Hasil Penelitian, 2017)

\section{Manfaat membuka akun media sosial}

Untuk mengetahui pandangan para pelajar mengenai manfaat membuka akun media sosial, dapat dilihat dari hasil penelitian menunjukkan angka 54\% 
menyatakan manfaat untuk mendapatkan berbagai informasi, 36\% untuk memudahkan berkomunikasi sesama teman sekolah dan teman di luar sekolah, 7\% untuk untuk tempat bertukar pikiran sesama teman, dan untuk menemukan teman, dan hanya $1 \%$ untuk menambah teman. Dari data ini menunjukan pada umum para pelajar di Kabupaten Bogor, bahwa dengan dengan membuka akun media sosial banyak memberikan banyak manfaat yang akan diperoleh.(Hasil Penelitian, 2017)

\section{Urgensi menggunakan fasilitas akun media sosial}

Untuk mengetahui pandangan para pelajar mengenai urgensi keberadaan media sosial untuk mendapatkan informasi dengan mengakses variasi aplikasi yang ada didalam media sosial, dapat dilihat hasil penelitian yang menunjukkan angka 52,7\% menyatakan urgensi aplikasi media sosial untuk mengakses ilmu pengetahuan yang ada kaitan dengan tugas di sekolah, 19,3\% untuk mencari pengetahuan umum lainnya, $11,3 \%$ untuk menghubungi teman, dan 10,7\% men-download lagu-lagu (hiburan).Hal ini menggambarkan para pelajar di Kabupaten Bogor bahwa menganggap fasilitas akun media sosial adalah penting untuk mengakses informasi. (Hasil Penelitian, 2017)

\section{Analisis Pemanfaatan Aplikasi Media Sosial dalam Pemilu Legislatif}

Pemanfaatan aplikasi media sosial tidak sebatas hanya untuk berkomunikasi secara umum, juga sekarang sudah merambah ke dunia politik, khusus dalam pemilu. Hal ini nampak jelas pada pemilu 2014 penggunaannya semakin meluas. Pada bagian ini merupakan gambaran pemanfaatan media sosial dikalangan pelajar sebagai pemilih pemula, yang diukur dengan: (a) Urgensi media sosial dalam pendidikan politik, (b) Urgensi pemanfaatan media sosial sebagai sarana sosialisasi politik, (c) Politisi menggunakan akun media sosial, (d)

\section{Urgensi aplikasi media sosial untuk pendidikan politik}

Pemanfaatan aplikasi media sosial di arena pemilu semakin meluas sekarang ini, hal ini karena media sosial memiliki daya jangkauan yang luas, dan dari segi biaya lebih murah ketimbang menggunakan media cetak klasik, misal spanduk, pamplet, liflet dan sebaginya, serta realitasnya masyarakat, khusus dikalangan pelajar yang rata-rata telah menggunakan berbagai aplikasi media sosial. Untuk mengetahui pandangan dari kalangan pelajar sebagai pemilih pemula di Kabupaten Bogor, mengenai urgensinya media sosial yang dimanfaatkan untuk pendidikan politik dalam rangka mencerdaskan pemilih, khususnya pemilih pemula. Merujuk hasil penelitian, menunjuk angka 96,3\% menyatakan penting media sosial sebagai medium pendidikan politik di kalangan pemilih pemula, dan 3\% menyatakan sangat penting, serta hanya $1 \%$ menyatakan tidak penting. Hal inijelas bahwa mayoritas pemilih pemula dikalangan pelajar di Kabupaten Bogor menganggap penting media sosial sebagai medium pendidikan politik. (Hasil Penelitian, 2017)

\section{Urgensi Media sosial dimanfaatkan untuk Sosialisasi Politik}

Pemilih pemula dikalangan pelajar di Kabupaten Bogor, hampir memiliki pandangan yang mayoritas terhadap urgensi media sosial dapat dimanfaatkan sebagai sarana untuk mensosialisasikan visi, misi, dan flatform (program kerja) kandidat anggota legislatif, sehingga mereka dapat mengambil keputusan yang cerdas untuk memilih. Hal ini ditujukkan dari hasil penelitian, bahwa 94,6\% menyatakan penting urgensi media sosial dimanfaatkan untuk mensosialisasikan visi, misi, dan flatform (program kerja) kandidat anggota legislatif, 4\% menyatakan sangat urgensi, dan hanya $1 \%$ menyatakan tidak penting urgensi. (Hasil Penelitian, 2017)

\section{Analisis Media Sosial sebagai Sarana untuk Menye- barkan Pengetahuan tentang Pemilu}

Telah disinggung di atas bahwa media sosial sudah menjadi trend dikalangan para politisi untuk menyebarkan informasi kepada khalayak, khususnya dikalangan para pelajar sebagai pemilih pemula tentang pengetahuan pemilu. Pada bagian ini merupakan gambaran pemanfaatan media sosial sebagai sarana untuk mengakses pengetahuan tentang pemilu, yang diukur dengan: (a) Mengetahui tentang pemilu legislatif dengan mengakses media sosial, (b)Sumber informasi lain tentang pemilu legislatif (c)Urgensi mengetahui informasi pemilu legislsatif.

\section{Mengakses Media Sosial untuk MendapatInformasi Pemilu Legislatif}

Dari hasil penelitian diketahui 98,7\% menyatakan mengetahui informasi pemilu legislatif dengan mengakses media sosial, dan hanya 1,3\% yang tidak pernah mengakses media sosial untuk mengetahui informasi tentang pemilu.Hal ini bermakna umumnya para pemilih pemula dikalangan pelajar di Kabupaten Bogor mengetahui informasi tentang pemilu dengan mengakses media sosial. (Hasil Penelitian, 2017)

\section{Sumber Informasi Lain tentang Pemilu Legislatif}

Selain mengetahui informasi tentang pemilihan pemilu legiastif melalui mengakses media sosial, juga didapatkan dari sumber lainnya. Untuk mengetahui sumber lainnya, ialah merujuk pada hasil penelitian yang menun-jukkan $61,3 \%$ bersumber dari televisi, 14\% dari Ibu/Bapak Guru pengajar mata pelajaran PKN, 9\% dari akun aplikasi media sosial yang dimiliki responden, sejumlah $8,7 \%$ dari orang tua di rumah, dan sejumlah 7,3\% dari para calon kandidat anggota legislatif melalui berbagai media sosial. Dari fakta tersebut di atas, 
menunjukkan pemilih pemula dari kalangan pelajar di Kabupaten Bogor selain mengakses media sosial, juga mendapatkan pengetahuan tentang pemilu legislatif dari televisi. (Hasil Penelitian, 2017)

\section{Urgensi Mengetahui Informasi Pemilu Legislsatif}

Indikator pentingnya mengetahui informasi tentang pemilu legislatif, dengan merujuk hasil penelitian yang menunjukkan angka 98,7\% menyatakan pentingnya mengetahui infomasi tentang pemilu legislatif, dan hanya $1,3 \%$ bependapat tidak penting. Hal ini bermakna mayoritas pemilih pemilu dikalangan pelajar di Kabupetan Bogor telah memiliki kesadaran bahwa pentingnya mengetahui informasi tentang pemilu legislatif. (Hasil Penelitian, 2017)

\section{Politisi Partai Politik Menggunakan Akun Media Sosial}

Pada umumnya, ada kecendrungan para politisi partai politik menggunakan akun media sosial untuk berbagai kepentingan, misalnya untuk menyampaikan visi dan misi serta program kerja, atau untuk penciteraan dirinya agar lebih dikenal khalayak dalam kampanye pemilu. Untuk mengetahui para politisi menggunakan akun media sosial untuk kepentingan kampanye, dapat diketahui dari hasil penelitian yang menunjukkan angka $82,7 \%$ menyatakan para politisi partai politik di Kabupaten Bogor sangat kurang menggunakan akun media sosial dan hanyan 17,3 \% yang mengatakan para politisi partai politik menggunakan akun media sosial dalam kampanye pemilu. (Hasil Penelitian, 2017)

\section{Politisi Penyampaian Visi dan Misi di Media Sosial}

Untuk mengetahui tingkat ketersetujuan pemilih pemula dikalangan pelajar di Kabupaten Bogor mengenai politisi perlu penyampaian visi dan misi sebagai kandidat anggota legislatif, dapat dilihat dari hasil penelitian yang menunjukkan angka $62 \%$ setuju partai politik memanfaatkan media sosial untuk penyampaian visi dan misi, dan 38\% yang berpendapat ketidak setujuan partai politik pemanfaatkan media sosial. Hal ini berarti sebagian besar pemilih pemula dikalangan pelajar di Kabupaten Bogor setuju para politisi ketika pemilu penyampaian visi dan misi melalui media sosial. Untuk memudahkan mendapatkan informasi mengenai apa yang akan dilakukan apabila terpilih. Hal ini pula yang akan dijadikan pertimbangan untuk memilih. (Hasil Penelitian, 2017)

\section{Keefektipan Kampanye melalui Media Sosial}

Dengan kemajuan teknologi informasi semakin dimudahkan untuk mendapat informasi, yang salah satunya melalui aplikasi media sosial. Karena itu semakin marak digunakan oleh para politisi dalam kampanye, dengan pertimbangan penggunaan akun media sosial sudah menyebar luas dan hampir tampa batas, pesan kampanye relatif berlangsung lebih cepat ketimbang menggunakan media kampanye konvesional seperti spanduk, baliho, lieflet, pamflet dan sebagainya. Untuk mengetahui pandangan dikalangan pelajar di Kabupaten Bogor mengenai keefektivan kampanye melalui media sosial dapat ditunjukkan dengan angka 73,3\% mengatakan sangat efektif apabila kampanye pemilu legislatif dengan memanfaatkan media sosial, dan 26,7\% mengatakan kurang efektif.Dari fakta ini, pemilih pemula dikalangan pelajar di Kabupaten Bogor menyatakan kampanye lebih efektif melalui media sosial, hal ini dapat dipahami karena sesuai dengan jiwa "anak muda" suka yang praktis. Mudah mendapatkan informasi dengan mengakses akun media yang mereka miliki, kapan dan dimana saja. (Hasil Penelitian, 2017)

\section{Analisis Konten (isi)Pesan Politik di Media Sosial}

Bagian ini menggambarkan konten (isi) pesan politik yang diharapkan mencakup: (1) Isi pesan kampanye politik menarik; (2) Isi pesan kampanye padat dan sederhana, dan (3) konten (isi) pesan kampanye dalam bentuk slogan dan bergambar animasi.

\section{Isi Pesan Kampanye Menarik}

Kampanye merupakan aktivitas kegiatan politik, karena itu yang terkait dalam kegiatan ini adalah komunikator, media, dan pesan politik. Ketiga komponen komunikasi tersebut akan mempengaruhi keberhasilan kampanye. Untuk mengetahui konten atau isi kampanye di media sosial, yang dibuat para politisi di Kabupaten Bogor menarik atau tidak, maka dapat dilihat dari hasil penelitian yang menunjukkan angka 73,5\% mengatakan bahwa isi pesan kampanye sangat tidak menarik, dan 26,7 mengatakan kurang menarik.Hal ini berarti isi pesan kampanye yang disebarkan di media sosial kurang mendapatkan respon positif dari pemulih pemula dari kalangan prelajar.Sebab isi pesan kampanye kurang sesuai dengan karakteristik pemilih pemula dari kalangan pelajar yang menyesukai hal-hal yang menarik. (Hasil Penelitian, 2017)

\section{Isi Pesan Kampanye Dibuat dengan Kalimat Singkat dan Padat}

Selain perlu dibuat menarik isi pesan kampanye itu, juga isi pesan kampanye perlu dibuat dengan kalimat singkat dan padat.Untuk mengetahui isi pesan kampanye dibuat dengan padat dan singkat, dapat dilihat dari hasil penelitian yang menunjukkan $86,7 \%$ menghendaki isi pesan kampanye dibuat secara singkat dan padat di media sosial, dan hanya 13,3\% mengatakan tidak perlu singkat dan padat. Dari fakta tersebut di atas, mayoritas kalangan pelajar di Kabupaten Bogor menghendaki isi pesan kampanye dikemas dengan kalimat singkat dan padat. Hal ini dapat dipahami karena jiwa "anak muda" selalu menghendaki hal-hal yang praktis. Misalnya, "Gunakanlah hak kesempatan anda untuk memilih, kalau tidak Anda akan menderita lima tahun kedepan." (Hasil Penelitian, 2017) 
Isi Pesan Kampanye Dibuat dengan Menggunakan Slogan dan diberi Gambar Animasi

Isi pesan kampanye pemilu yang ditujukan kepada kalangan para pelajar di media sosial dikemas dengan kalimat slogan dan gambar animasi.Hal ini sesuai dengan karakteristik anak muda hal-hal yang menarik perhatian. Berdasarkan hasil penelitian menunjukkan angka 94\% para pemilih pemula dari kalangan pelajar di Kabupaten Bogor suka isi pesan kampanye pemilu dibuat dalam bentuk slogan dan diberi gambar animasi, dan 5\% kurang suka, serta hanya $1 \%$ tidak suka. Dari fakta tersebut mayoritas kalangan pelajar di Kabupaten Bogor menyukai isi pesan kampanye di media sosial dikemas selain dalam bentuk slogan juga diberi gambar animasi agar lebih menarik.Ini sesuai dengan karakteristik jiwa anak muda yang umumnya menyukai objek yang memberikan daya tarik mereka.Misalnya, dengan kalimat bahasa "gaul"; “Coblos Keren, Kabupaten Bogor Maju!"

\section{SIMPULAN}

Dari seluruh uraian pembahasan dapat diambil beberapa kesimpulan, yaitu: (1) Para politisi di Kabupaten Bogor, belum mampu mengoptimalkan pemanfaatkan aplikasi media sosial berbasis internet untuk kepentingan kampanye dalam rangka peningkatan partisipasi pemilih pemula dari kalangan pelajar, (2) Para politisi kurang mampu memanfaatan potensi pemilih pemula dikalangan pelajar yang mayoritas telah memiliki akun media sosial untuk kepentingan kampanye pemilu legislatif di Kabupaten Bogor, (3) Penggunakan fasilitas akun media sosial belum dianggap urgen, dan (4) Pada umumnya konten (isi) pesan kampanye yang dimuat di media sosial kurang memiliki daya tarik. Karena konten (isi) kampanye dikemas belum sesuai dengan karakteristik pemilih pemula dikalangan pelajar.Misalnya dikemas dalam bentuk kalimat sederhana, singkat, padat, dan berupa slogan serta diberi gambar dan animasi.

Isi pesan politik dalam kampanye belum dikemas sesuai dengan karakteristik para pemilih pemula. Dari aspek pengetahuan tentang Pemilihan Umum, pemilih pemula sudah banyak mengetahui melalui dengan mengakses aplikasi melalui smartphone atau internet.

\section{UCAPAN TERIMAKASIH}

Direktorat Riset dan Pengabdian Masyarakat Direktorat Jenderal Penguatan Riset dan Pengembangan Kemen- terian Riset, Teknologi dan Pendidikan Tinggi Sesuai dengan Kontrak Penelitian No. 1598/K4/KM/2017 Tahun Anggaran 2017

\section{DAFTAR PUSTAKA}

Budiardjo, M. (2008). Dasar-Dasar Ilmu Politik. Jakarta: PT. Gramedia Pustaka Utama.

Cangara, H. (2006). Pengantar Ilmu Komunikasi. Jakarta: PT. Raja Grafindo Persada.

Departemen Pendidikan Nasional. (2005). Kamus Besar Bahasa Indonesia. Jakarta: Balai Pustaka.

Mingkid, E. (2015). Penggunaan Media Komunikasi Promosi Pariwisata Oleh Pemerintah Kota Manado. Sosiohumaniora Vol. 18 (3): 188-192.

Michael, R. dan Philip. A. (2008). Pengantar Sosiologi Politik. Jakarta: PT. Raja Grafindo Persada.

Nasrullah, R. (2017). Media Sosial: Perspektif Komunikasi, Budaya, dan Sosioteknologi. Bandung: Remaja Rosdakarya.

Prasetya, A.B. (2013). Kiprah New Media dalam Percaturan Politik di Indonesia. Bandung: Sosiohumaniora Vol. 15 (3): 232-238.

Maran, R. (2001). Pengantar Sosiologi Politik. Jakarta: Rineka Cipta.

Sugiyono, (2014). Metode Penelitian Kombinasi (Mix Methodes). Bandung: Penerbit Alfabeta.

Surbakti, R. (2000). Memahami Ilmu Politik. Jakarta: PT. Gramedia Widiasarana Indonesia.

Undang-Undang Nomor 8 Tahun 2012 Tentang Pemilihan Umum Modul KPU (Modul I Pemilih Untuk Pemula. 2010.

Undang-Undang Nomor 15 tahun 2011 tentang Penyelenggara Pemilu.

Winarno, S. (2002). Pengantar Penelitian Ilmiah, Dasar, Metode, dan Teknik. Bandung: Tarsito.

http://digilib.unila.ac.id/12294/3/BAB\%20II.pdfdiakses 16 Februari 2017.

http://nasional.kompas.com/read/2014/06/24/0245002/ diakses 02 Februari 2017.

http://www.pemilu.go.id diakses 06 Januari 2016. 